\title{
PEMANFAATAN SLUDGE INDUSTRI PULP DAN KERTAS UNTUK AMELIORASI TANAH TAILING TAMBANG EMAS
}

\author{
Enny Widyati \\ Peneliti Biologi Tanah dan Kesuburan Lahan \\ Pusat Litbang Konservasi dan Rehabilitasi \\ Jl. Gunung Batu No. 5, Bogor \\ e-mail : enny_widyati@yahoo.com
}

Diterima : 06 Maret 2012, Revisi akhir : 19 Juni 2012

\section{THE USE OF PULP AND PAPER MILLS SLUDGE FOR SOIL AMELIORATION OF GOLD TAILING}

\begin{abstract}
Mine tailings generally have low fertility, and also high concentration of metals. Amelioration with soil organic is one of proper efforts. Sludge of pulp and paper mills can be an alternative of soil organic source. This research is aimed to improve chemical properties of mine tailing. The study was conducted in randomized completely design with dosages of 25 and $50 \%$ of tailing added into tailing pond and tailing dump. Observation of $N, P, K, p H$ and CEC were conducted in the days of $0,5,10$ and 15 after incubation, whereas the content of $\mathrm{S}, \mathrm{Pb}, \mathrm{Cd}, \mathrm{Cu}, \mathrm{Fe}$ and $\mathrm{CN}$ were measured in the days of 0,7 and 15 after incubation. The result showed that sludge in dosage 50\% was the most effective in improving the properties of the tailings in 15 days after incubation. Efficiency of improvements were, 2,414\% for $N$ tailing dump and 3,243\% for $N$ tailing pond; $P(>440 \%)$, CEC $(>150 \%)$; The dosage of $50 \%$ as well as reduce the content of S (82\%), $\mathrm{Fe}$ (63\%), $\mathrm{Cu}(73 \%), \mathrm{Cd}(90 \%), \mathrm{Pb}(53 \%)$, and cyanide (99\%), respectively. This research suggested that slude of paper mills is effective to improve mine tailing properties.
\end{abstract}

Keywords: amelioration, mine tailing, pulp and paper mills sludge

\begin{abstract}
ABSTRAK
Tailing tambang umumnya memiliki kandungan unsur-unsur hara yang rendah atau sifat kimia tanah yang buruk dan mengandung logam-logam yang berbahaya bagi lingkungan. Oleh karena itu, ameliorasi timbunan tailing dengan bahan organik merupakan salah satu upaya yang tepat. Sludge industri kertas merupakan salah satu sumber bahan organik yang dapat dijadikan amelioran. Tujuan penelitian ini adalah untuk menguji apakah sludge industri pulp dan kertas dapat memperbaiki sifat-sifat kimia tanah timbunan tailing bekas tambang emas. Penelitian dilakukan menggunakan rancangan dasar acak lengkap secara faktorial, dengan perlakuan penambahan 25 dan $50 \%$ sludge ke dalam tailing pond dan tailing dump, berturut-turut sebagai faktor pertama dan kedua. Parameter-parameter yang diamati meliputi ketersediaan $\mathrm{N}, \mathrm{P}, \mathrm{K}, \mathrm{pH}, \mathrm{KTK}$ dilakukan pada hari ke $0,5,10$ dan 15 serta ketersediaan $\mathrm{S}, \mathrm{Pb}$, $\mathrm{Cd}, \mathrm{Cu}, \mathrm{Fe}, \mathrm{CN}$ pada hari ke 0,7 dan 15 setelah inkubasi. Hasil penelitian menunjukkan bahwa sludge dengan dosis 50\% efektif memperbaiki sifat-sifat kimia tailing dengan waktu inkubasi 15 hari. Dosis tersebut dapat meningkatkan ketersediaan $\mathrm{N}$ dengan efisiensi $2414 \%$ untuk tailing dump dan 3243\% untuk tailing pond, meningkatkan ketersediaan P lebih dari 440\%, dan meningkatkan KTK lebih dari $150 \%$. Dosis tersebut juga efektif dalam menurunkan ketersediaan S (82\%), $\mathrm{Fe}(63 \%), \mathrm{Cu}(73 \%), \mathrm{Cd}$ (90\%), $\mathrm{Pb}(53 \%)$ dan menurunkan ketersediaan sianida sebesar $99 \%$.
\end{abstract}

Kata kunci: ameliorasi, sludge industri pulp dan kertas, tailing tambang 


\section{PENDAHULUAN}

Data tahun 2005 menyebutkan bahwa Indonesia menduduki peringkat ke-2 sebagai negara pengekspor batubara, penghasil timah peringkat ke-2, tembaga ke-3, dan nikel ke-4 (Gautama, 2007). Untuk tambang emas Indonesia menempati peringkat ke-8 dunia (Gautama, 2007). Secara keseluruhan kekayaan tambang Indonesia menempati urutan ke-6 dunia (CEO PT. INCO diberitakan Harian Berita Sore Makassar 11 Februari 2009). Namun belum ada data rinci berapa total potensi cadangan bahan tambang Indonesia.

Cadangan bahan galian Indonesia selain cukup besar juga tersebar di berbagai daerah, sehingga kekayaan nasional yang berupa bahan tambang cukup merata. Di Pulau Bangka terdapat pertambangan timah, di Pulau Bintan aluminium, di Sumatera Selatan terdapat batubara, demikian juga di Kalimantan Timur dan Kalimantan Selatan. Di Kalimantan Tengah dan Kalimantan Barat terdapat pertambangan emas, di Sulawesi ditemukan tambang nikel, sedangkan di Papua, Nusa Tenggara dan Minahasa terdapat tambang tembaga dan emas, dll (www.dpmb.esdm.go.id).

Emas, tembaga, nikel, perak, atau mineral yang ditambang di alam terdapat bersama sama dengan mineral lainnya dalam bentuk batuan. Oleh karena itu, untuk mengekstrak mineral yang diinginkan, batuan harus digerus kemudian dimurnikan dan bahan lain yang tidak diinginkan akan dibuang. Pertambangan mineral selalu meninggalkan limbah berupa tanah dan batuan besar bekas penambangan yang disebut rockdump dan batuan halus bekas pengolahan yang disebut tailing.

Tailing merupakan salah satu bentuk limbah yang dihasilkan dalam jumlah banyak pada kegiatan pertambangan emas. Jumlah tailing yang dihasilkan oleh perusahaan pertambangan skala besar dapat mencapai 2.500 ton per hari (Fauziah 2009). Sebagai contoh, PT Freeport (Papua) yang dikenal mengandung konsentrat terbesar cadangan emas di Indonesia, untuk mendapat satu gram emas dibuang 650 kilogram limbah tailing dan 1.730 kilogram overburden (Hidayat, dkk., 2007). Menurut Maemunah (2007), untuk mendapatkan satu gram emas dihasilkan 2,1 ton limbah batuan dan lumpur tailing, yang diantaranya mengandung 260 gram timbal; 6,1 gram merkuri dan 3 gram sianida. Jadi apabila seseorang mempunyai 20 gram emas maka dia telah menyumbangkan 10 truk limbah ke lingkungan (www.jatam.org). Besarnya limbah batuan yang dihasilkan disebabkan karena bahan galian yang benar-benar menjadi konsentrat jumlahnya sangat sedikit.

Menurut Setyawan (2004), tailing adalah ampas mineral yang terdiri dari $30 \%$ fraksi padat dan $70 \%$ fraksi cair, mengandung logam-logam berat seperti antimon ( $\mathrm{Sb}$ ), arsen (As), sianida $(\mathrm{CN})$, merkuri $(\mathrm{Hg})$, tembaga $(\mathrm{Cu})$, dan perak (Ag) yang akan mencemari lingkungan. Masingmasing tailing memiliki karakter yang berbeda sesuai dengan mineral yang ditambang dan senyawa kimia tertentu yang ditambahkan untuk mempercepat proses pemurnian bijih. Anonim (2012) menyebutkan bahwa tailing tambang timah umumnya mengandung $\mathrm{Na}, \mathrm{Ca}, \mathrm{Mg}$, $\mathrm{Al}$ dan $\mathrm{Pb}$. Bekas tailing tambang nikel mengandung $\mathrm{Ca}$, $\mathrm{Mg}, \mathrm{Fe}, \mathrm{Co}$ dan Ni. Adapun tailing tambang emas umumnya mengandung $\mathrm{Ag}, \mathrm{Al}, \mathrm{As}, \mathrm{Ca}, \mathrm{Cd}, \mathrm{Cu}$, $\mathrm{Cr}, \mathrm{Fe}, \mathrm{Hg}, \mathrm{Pb}, \mathrm{Mg}, \mathrm{Se}, \mathrm{Ni}, \mathrm{Zn}$ dan $\mathrm{Na}$. Karena tailing mengandung logam berat maka menurut Peraturan Pemerintah (PP) No 18 tahun 1999 tentang Pengelolaan Limbah Bahan Beracun dan Berbahaya (B3) jo PP No 85 tahun 1999, termasuk dalam kategori limbah B3.

Pengelolaan yang tepat terhadap limbah tailing tambang adalah Submarine Tailing Disposal (STD) atau Sistem Penempatan Tailing Bawah Laut (SPTBL), yang merupakan salah satu cara pembuangan limbah yang baik dan ramah lingkungan. Dua tambang di Indonesia yang menggunakan SPTBL adalah tambang di Lembata dan PT. Newmont (www.jatam.org). Namun demikian, sistem pengelolaan tailing STD tersebut tidak akan dapat dilakukan ketika lokasi penambangan berada jauh dari laut.

Upaya pengelolaan tailing lain yang dapat dilakukan salah satunya dengan penanaman (revegetasi) pada lahan penimbunan tailing tersebut atau pemanfaatan tailing sebagai media tanaman kehutanan atau perkebunan. Namun demikian, karena tailing berasal dari batuan yang memiliki kesuburan yang sangat rendah maka dapat menghambat upaya penanaman pada lahan penimbunan tailing tersebut. Di samping itu logam-logam berat yang terkandung dalam tailing akan terakumulasi dalam akar sehingga dapat mengganggu penyerapan unsur hara dan dapat mengganggu pertumbuhan tanaman (Alloway, 1995). Penelitian Kshirsagar and Aery (2007) pada tanah tailing tanpa perlakuan tanaman Vigna unguilata yang ditumbuhkan sebagai pionir tidak 
dapat berkecambah sama sekali tetapi setelah perlakuan penambahan pupuk kandang 25 ton/ha dan NPK $60 \mathrm{~kg} / \mathrm{ha}$ maka tanaman tersebut dapat tumbuh dengan baik.

Oleh karena itu, pemanfaatan lahan penimbunan tailing memerlukan upaya ameliorasi dengan bahan organik, baik untuk memperbaiki kesuburan maupun untuk menurunkan ketersediaan logam-logam dalam tailing tersebut. Beberapa hasil penelitian menunjukkan bahwa ameliorasi tailing dengan bahan organik dapat meningkatkan pertumbuhan tanaman yang ditanam pada media tailing tersebut. Sitorus dkk., (2008) melakukan penelitian revegetasi pada tailing tambang timah di Bangka, hasil terbaik diberikan oleh perlakuan penambahan bahan amelioran organik, pemilihan jenis tanaman yang tepat serta penambahan inokulum mikoriza untuk membantupertumbuhantanaman. Hasilpenelitian Siregar (2005) menunjukkan bahwa penambahan pupuk organik pupuk kandang pada tanah tailing dapat menurunkan kelarutan $\mathrm{Pb}$ dan Fe sehingga dapat memperbaiki pertumbuhan tanaman sengon. Demikian juga Wasis dan Sandrasari (2011) menjelaskan bahwa pertumbuhan bibit Mahoni yang ditanam pada media tailing dapat diperbaiki dengan penambahan kompos 30 gram per polibag.

Jumlah tailing yang sangat besar dan terus dihasilkan selama masih berlangsung proses penambangan akan memerlukan bahan organik dalam jumlah yang besar dan pasokan yang berkesinambungan. Misalnya ameliorasi yang dilakukan untuk memfasilitasi suksesi alam pada tailing bekas tambang intan di Afrika Selatan yang paling optimal adalah pemberian vermikompos 60 ton/ha ditambah pupuk $\mathrm{Ca}\left(\mathrm{NO}_{3}\right)_{2}(25 \mathrm{~kg} / \mathrm{ha})$ and $\mathrm{Mg}\left(\mathrm{NO}_{3}\right)_{2}(12,5 \mathrm{~kg} / \mathrm{ha})$ (Rosenburg, dkk., 2004). Dengan demikian, penggunaan bahan amelioran di lapangan tidak akan dapat dipenuhi apabila mengandalkan bahan organik dari kompos atau pupuk kandang. Salah satu sumber bahan organik yang belum banyak dimanfaatkan untuk sektor pertanian tetapi tersedia dalam jumlah besar dan berkesinambungan adalah sludge industri pulp dan kertas. Widyati (2006) telah menguji pemanfaatan sludge industri pulp dan kertas untuk ameliorasi tanah bekas tambang batubara. Sludge pulp dan kertas dengan dosis $25 \%$ (v/v) dapat meningkatkan $\mathrm{pH}$, KTK dan ketersediaan unsur hara makro serta menurunkan ketersediaan $\mathrm{Fe}$, $\mathrm{Mn}, \mathrm{Zn}$, dan Cu secara signifikan pada tanah bekas tambang batubara. Adapun pada aplikasi sludge pada dosis $50 \%(\mathrm{v} / \mathrm{v})$ pada tanah bekas tambang batubara dapat meningkatkan ketersediaan $\mathrm{C}, \mathrm{N}$, $\mathrm{P}$ dan $\mathrm{K}$ berturut-turut sebesar $180 \%, 3.050 \%$, $4.766 \%$ dan $295 \%$ serta mereduksi ketersediaan $\mathrm{Fe}, \mathrm{Mn}, \mathrm{Zn}$ dan $\mathrm{Cu}$ berturut-turut sebesar 99\%; $48 \% ; 78 \%$ dan $63 \%$ dalam waktu 15 hari.

Tujuan dari penelitian ini adalah untuk menguji apakah sludge industri pulp dan kertas dapat dimanfaatkan untuk memperbaiki sifatsifat kimia tailing dan mendapatkan dosis sludge yang efektif dalam memperbaiki sifat-sifat tailing sehingga menjadi media tumbuh yang dapat mendukung pertumbuhan tanaman. Dengan dapat dimanfaatkannya sludge industri pulp dan kertas sebagai bahan amelioran tailing menjadi bahan yang bisa mendukung pertumbuhan tanaman, diharapkan akan dapat membantu sektor pertambangan menangani masalah tailing serta membantu industri pulp dan kertas mengatasi pengelolaan limbah sludge menjadi produk samping yang bermanfaat.

\section{BAHAN DAN METODE}

Tailing diambil dari tambang emas di Pongkor, Bogor terdiri atas tailing pond dan tailing dump. Tailing pond merupakan tailing yang berada di dalam kolam pengendap, sedangkan tailing dump diambil dari lokasi penimbunan tailing. Sludge diambil dari PT. Indah Kiat Pulp and Paper (IKPP) di Perawang, Riau. Sludge diambil dari instalasi IPAL yang baru keluar dari mesin dewatering dengan kadar air kurang lebih 70\%. Percobaan dilakukan di rumah kaca, secara faktorial dengan perlakuan ditempatkan menurut rancangan acak lengkap (RAL). Susunan perlakuan adalah sebagai berikut:

- $100 \%$ tailing pond sebagai kontrol 1 (TP)

- $75 \%$ tailing pond: $25 \%$ sludge (v/v) $(\mathrm{TP}+25 \%$ sludge $)$

- 50\% tailing pond: $50 \%$ sludge (v/v) $(\mathrm{TP}+50 \%$ sludge $)$

- $100 \%$ tailing dump sebagai kontrol 2 (TD)

- $75 \%$ tailing dump: $25 \%$ sludge (v/v) (TD $+25 \%$ sludge)

- 50\% tailing dump: $50 \%$ sludge (v/v) $(\mathrm{TD}+50 \%$ sludge $)$

Setelah masing-masing bahan (tailing dan sludge) ditakar/ditimbang sesuai perlakuan, kemudian dicampur sampai rata. Setelah dicampur, masing-masing bahan setiap 
perlakuan ditempatkan ke dalam polibag berukuran $20 \times 20 \mathrm{~cm}$, kemudian ditempatkan di rumah kaca. Kelembaban media bahan diatur $60 \%$ yang diukur setiap tiga hari. Apabila hasil pengukuran kadar air campuran bahan di dalam polibag menunjukkan $<60 \%$, maka dilakukan penyiraman.

Percobaan dilakukan dalam 3 kali ulangan. Pada hari ke-0, 5, 10, dan 15 dilakukan pengamatan kandungan unsur hara makro dan pH; sedangkan pengamatan KTK dilakukan pada hari ke-0 dan hari ke-15. Pada hari pengamatan tersebut diambil sampel tailing yang telah diberi perlakuan kemudian dikirim untuk dianalisis di Laboratorium Kimia dan Kesuburan Tanah, Institut Pertanian Bogor. Pengaruh perlakuan terhadap kandungan logam berat dilakukan pada salah satu jenis tailing yang lebih berat kondisinya menurut hasil karakterisasi awal. Pengamatan perubahan konsentrasi logam berat dilakukan pada hari ke-0, 7 dan 15 setelah inkubasi.

\section{HASIL DAN PEMBAHASAN}

\section{A. Karakterisasi Awal Tailing dan Sludge}

Tabel 1 menunjukkan bahwa secara umum tailing memiliki kandungan unsur-unsur hara/kimia yang sangat rendah. Tabel 1 juga menunjukkan tailing memiliki total fosfor yang sangat tinggi, yang diduga berasal dari bahan induk asal tailing. Akan tetapi, ketersediaan $\mathrm{P}$ pada kedua tailing tergolong rendah, hal ini diduga diakibatkan oleh nilai $\mathrm{pH}$ yang tinggi, kandungan bahan organik dalam tailing yang sangat rendah serta kandungan $\mathrm{Ca}$ yang tinggi. Hal ini sejalan dengan Tan (1993) bahwa ketika pH cenderung basa maka $\mathrm{P}$ akan terkelat oleh unsur Ca. Sludge memiliki nilai P-tersedia yang tinggi dikarenakan adanya residu dari pemberian pupuk $\mathrm{P}$ dalam bentuk asam fosfat cair selama proses pengolahan sludge dalam instalasi pengolahan air limbah (IPAL).

Hasil karakterisasi awal kandungan total logam, sulfur dan sianida (Tabel 2) menunjukkan bahwa tailing memiliki kandungan sulfur dan logam-logam yang jauh melampaui ambang batas yang dapat ditoleransi oleh tanah, karena merupakan bahan induk bijih tambang. Walaupun antara tailing pond dan tailing dump tidak menunjukkan perbedaan sifat-sifat kimia yang nyata, namun tailing dump cenderung mengakumulasikan logam-logam tersebut lebih tinggi. Hal ini diduga pada tailing pond kadar airnya masih sangat tinggi sehingga ionion logam larut dalam air dan terbuang ketika terjadi limpasan. Sedangkan pada tailing dump kondisinya sudah benar-benar kering. Hal ini karena tailing mengandung bahan organik yang sangat rendah (Tabel 1) sehingga tidak dapat menahan air ketika dilakukan penumpukan.

Secara fisik, kedua jenis tailing memiliki tekstur pasir berdebu, hal ini yang menyebabkan tailing sulit mengikat air walaupun tailing pond berada dalam kolam pengendap dan tailing dump terdapat pada tempat penumpukan.

\section{Pengaruh Penambahan Sludge terhadap Kandungan Unsur Hara Makro pada Tailing}

\section{Pengaruh Sludge terhadap Kandungan N Total}

Tabel 3 menunjukkan kandungan $\mathrm{N}$ dalam tailing menurut kriteria Pusat Penelitian Tanah (1993) tergolong sangat rendah, karena tingkat kecukupan $\mathrm{N}$ bagi semua jenis tanaman minimal 1\% (Havlin, dkk., 1999). Penambahan sludge $50 \%$ dapat meningkatkan nilai total $\mathrm{N}$ baik pada tailing pond maupun tailing dump pada hari ke-15 setelah inkubasi. Walaupun peningkatan tersebut masih jauh dari angka kecukupan $\mathrm{N}$ namun kalau dilihat nilai efisiensinya (Tabel 9) penambahan sludge $50 \%$ meningkatkan kandungan $\mathrm{N}$ total $2.414 \%$ pada tailing pond dan $3.243 \%$ pada tailing dump. Hal ini sejalan dengan penelitian N'Dayegamiye (2009) yang mengaplikasikan kompos sludge pada beberapa dosis pada tanaman jagung yang ditanam pada lahan berpasir dapat menurunkan penggunaan pupuk $\mathrm{N}$ antara $40 \%$ sampai tergantikan sama sekali. Peningkatan $\mathrm{N}$ yang signifikan ini terjadi diduga karena adanya pelepasan $\mathrm{N}$ dari sludge memiliki kandungan $\mathrm{N}$ total yang sangat tinggi (Tabel 1). Namun demikian, dinamika yang terjadi pada perubahan ketersediaan $\mathrm{N}$ pada hari ke-5 dan ke-10 cenderung mengalami penurunan dan baru terjadi peningkatan yang signifikan pada hari ke-15 (Tabel 2), maka kuat diduga bahwa yang menyebabkan meningkatnya ketersediaan $\mathrm{N}$ adalah akibat aktivitas mikroba yang terdapat dalam sludge. Pada hari ke-5 dan ke-10 diduga sistem sedang mengalami proses menuju kesetimbangan, sedangkan pada hari ke-15 sistem sudah berjalan secara stabil dalam memperbaiki ketersediaan $\mathrm{N}$. 
Tabel 1. Hasil Analisis Awal Tailing Pond, Tailing Dump, dan Sludge

\begin{tabular}{|c|c|c|c|c|c|c|c|}
\hline \multirow{3}{*}{ No. } & \multirow{3}{*}{ Parameter } & \multirow{2}{*}{\multicolumn{3}{|c|}{ Nilai }} & \multicolumn{3}{|c|}{ Kriteria } \\
\hline & & & & & \multicolumn{3}{|c|}{ (Pusat Penelitian Tanah, 1993) } \\
\hline & & $\mathrm{TP}$ & $\mathrm{TD}$ & Sludge & $\mathrm{TP}$ & TD & Sludge \\
\hline 1 & $\mathrm{pH} \mathrm{H} \mathrm{H}_{2} \mathrm{O}$ & 7,23 & 7,47 & 4,17 & netral & netral & sangat asam \\
\hline 2 & C Organik (\%) & 0,29 & 0,32 & 14,7 & sangat rendah & sangat rendah & sangat tinggi \\
\hline 3 & N-Total (\%) & 0,009 & 0,012 & 2,621 & sangat rendah & sangat rendah & tinggi \\
\hline 4 & P tersedia (ppm) & 4,88 & 4,33 & 46,98 & sangat rendah & sangat rendah & sangat tinggi \\
\hline 5 & P Total (ppm) & 1864,7 & 1954,9 & 586,2 & tinggi & tinggi & tinggi \\
\hline 6 & Fe tersedia (ppm) & 14,62 & 13,69 & 3,80 & berlebih & berlebih & cukup \\
\hline 7 & $\mathrm{Cu}$ tersedia (ppm) & 0,463 & 0,467 & 0,037 & cukup & cukup & defisiensi \\
\hline 8 & Mn tersedia (ppm) & 2,427 & 2,703 & 0,057 & cukup & cukup & defisiensi \\
\hline 9 & Zn tersedia $(\mathrm{ppm})$ & 0,65 & 0,50 & 0,11 & marginal & marginal & defisiensi \\
\hline 10 & $\mathrm{Ca}(\mathrm{me} / 100 \mathrm{~g})$ & 13,34 & 12,30 & 1,54 & tinggi & tinggi & sangat rendah \\
\hline 11 & $\mathrm{Mg}(\mathrm{me} / 100 \mathrm{~g})$ & 0,266 & 0,301 & 0,992 & sangat Rendah & rendah & sangat tinggi \\
\hline 12 & $\mathrm{~K}(\mathrm{me} / 100 \mathrm{~g})$ & 0,050 & 0,047 & 0,061 & sangat rendah & sangat rendah & sangat rendah \\
\hline 13 & $\mathrm{Na}(\mathrm{me} / 100 \mathrm{~g})$ & 0,65 & 0,36 & 0,23 & sedang & sedang & rendah \\
\hline 15 & KTK (me/100g) & 5,415 & 5,603 & 22,724 & rendah & rendah & sedang \\
\hline 16 & Kejenuhan Basa (\%) & 273,64 & 234,33 & 12,43 & sangat tinggi & sangat tinggi & sangat rendah \\
\hline 17 & Debu $(\%)$ & 22 & 16 & - & & & \\
\hline 18 & Pasir (\%) & 59 & 71 & - & pasir berdebu & pasir berdebu & - \\
\hline 19 & Liat (\%) & 19 & 13 & - & & & \\
\hline
\end{tabular}

Sumber: Hasil Analisis Laboratorium

Tabel 2. Kandungan Total Beberapa Logam, S dan Sianida (ppm) pada Tailing Tambang Emas

\begin{tabular}{ccc}
\hline Parameter (dalam ppm) & Tailing Pond & Tailing Dump \\
\hline $\mathrm{Pb}$ & 138,71 & 158,42 \\
$\mathrm{Cd}$ & 9,97 & 13,21 \\
$\mathrm{Ag}$ & 2,21 & 1,98 \\
$\mathrm{CN}$ & 1,44 & 0,76 \\
$\mathrm{Fe}$ & 18997 & 21269 \\
$\mathrm{Cu}$ & 98,41 & 112,02 \\
$\mathrm{~S}$ & 6241 & 8623 \\
\hline
\end{tabular}


Tabel 3. Pengaruh Sludge terhadap Kandungan N-Total pada Tailing (\%)

\begin{tabular}{|c|c|c|c|c|}
\hline \multirow{2}{*}{ Perlakuan } & \multicolumn{4}{|c|}{ Waktu (Hari ke-) } \\
\hline & 0 & 5 & 10 & 15 \\
\hline Tailing pond (TP) & 0,007 (a) (A) & 0,005 (a) (A) & 0,007 (a) (A) & 0,007 (a) (A) \\
\hline $\mathrm{TP}+25 \%$ sludge & 0,060 (b) (B) & 0,055 (b) (B) & 0,035 (b) (A) & 0,079 (b) (C) \\
\hline $\mathrm{TP}+50 \%$ sludge & $0,086(\mathrm{~b})(\mathrm{B})$ & $0,074(\mathrm{~b})(\mathrm{A})$ & $0,072(\mathrm{~b})(\mathrm{A})$ & $0,176(\mathrm{c})(\mathrm{C})$ \\
\hline Tailing dump (TD) & 0,009 (a) (A) & 0,009 (a) (A) & 0,009 (a) (A) & 0,007 (a) (A) \\
\hline $\mathrm{TD}+25 \%$ sludge & 0,090 (b) (B) & $0,060(\mathrm{~b})(\mathrm{A})$ & $0,069(\mathrm{~b})(\mathrm{A})$ & 0,083 (b) (B) \\
\hline $\mathrm{TD}+50 \%$ sludge & $0,169(\mathrm{c})(\mathrm{B})$ & $0,141(\mathrm{c})(\mathrm{A})$ & 0,183 (c) (C) & $0,229(\mathrm{c})(\mathrm{D})$ \\
\hline
\end{tabular}

Keterangan: angka-angka yang diikuti oleh huruf kecil yang sama dalam kolom yang sama dan angka-angka yang diikuti oleh huruf besar yang sama dalam baris yang sama menunjukkan tidak berbeda nyata menurut uji DMRT pada selang kepercayaan $95 \%$

\section{Pengaruh Sludge terhadap Ketersediaan Fosfor (P) Tailing}

Tabel 4 menunjukkan bahwa dosis sludge yang efektif untuk meningkatkan ketersediaan $\mathrm{P}$ baik pada tailing pond maupun tailing dump adalah 50\%. Dosis tersebut dapat meningkatkan ketersediaan P secara signifikan sejak hari pertama perlakuan. Peningkatan ketersediaan $\mathrm{P}$ walaupun secara statistik menunjukkan perbedaan yang nyata namun apabila dikategorikan menurut Pusat Penelitian Tanah (1983) menunjukkan perubahan angka yang lambat. Lambatnya laju peningkatan P-tersedia pada tailing dikarenakan sifat fosfor yang sukar larut dalam air (Witoko, 2011), tailing pond memiliki kandungan air ratarata $180 \%$, sedangkan tailing dump $48 \%$. Nilai P-tersedia meningkat walaupun secara perlahan diduga dikarenakan pengaruh pelepasan $\mathrm{P}$ dari sludge sehingga dapat memberikan fosfor dalam bentuk P-tersedia. Di samping itu, sludge adalah bahan organik yang menurut Bear (1985) dalam Andri (2006), bahan organik mengandung asam organik seperti asam tartat, asam malonat, dan asam malat dapat mencegah unsur besi dan alumunium bereaksi dengan fosfat sehingga tidak terjadi endapan yang menyebabkan P menjadi tidak tersedia.

Dinamika yang terjadi pada perubahan ketersediaan $\mathrm{P}$ pada masing-masing perlakuan cukup beragam (Tabel 4). Untuk perlakuan tailing pond dengan penambahan sludge $25 \%$ peningkatan terjadi pada hari ke-5 dan makin meningkat sejalan dengan penambahan waktu inkubasi. Sedangkan untuk penambahan 50\% sludge perubahan signifikan terjadi pada hari perlakuan, kemudian terjadi stagnasi sampai pada hari ke-10 selanjutnya terjadi lagi peningkatan secara signifikan pada hari ke-15. Untuk tailing dump perubahan yang terjadi baik pada penambahan sludge 25\% maupun 50\% terjadi secara bertahap. Pada hari perlakuan sudah terjadi peningkatan secara signifikan, perubahan makin meningkat secara signifikan sejalan dengan penambahan waktu inkubasi.

\section{Pengaruh Sludge terhadap Ketersediaan K dalam Tailing}

Penambahan sludge ternyata tidak berpengaruh terhadap ketersediaan $\mathrm{K}$ dalam tailing (Tabel 5). Hal ini karena sludge juga mengandung $\mathrm{K}$ yang sangat rendah (Tabel 1). Faktor utama kehilangan kalium dalam tailing diduga disebabkan oleh pencucian selama proses ekstraksi emas. Penambahan sludge pada Tabel 5 menunjukkan kecenderengunan menurunkan kandungan $\mathrm{K}$ tersedia. Hal ini diduga $\mathrm{K}$ tersebut dimanfaatkan oleh mikroba yang terdapat pada sludge.

\section{B. Pengaruh Sludge terhadap $\mathrm{pH}$ dan KTK Tailing}

Tabel 6 menunjukkan bahwa $\mathrm{pH}$ tailing termasuk mendekati basa. Hal ini karena tailing berasal dari penggerusan batuan yang mengandung banyak logam-logam atau kationkation basa, di samping itu sebelum tailing dibuang umumnya dilakukan pengapuran. 
Tabel 4. Pengaruh Sludge terhadap Kandungan P-tersedia pada Tailing (ppm)

\begin{tabular}{ccccc}
\hline \multirow{2}{*}{ Perlakuan } & \multicolumn{4}{c}{ Waktu (Hari ke-) } \\
\cline { 2 - 5 } & 0 & 5 & 10 & 15 \\
\hline Tailing pond (TP) & $4,88(\mathrm{a})(\mathrm{A})$ & $4,16(\mathrm{a})(\mathrm{A})$ & 4,68 (a) (A) & 5,07 (b) (B) \\
TP + 25\% sludge & 4,57 (a) (A) & 7,25 (b) (B) & 8,68 (c) (C) & 9,77 (c) (D) \\
TP + 50\% sludge & 8,84 (c) (A) & 8,15 (b) (A) & 8,86 (c) (A) & 12,24 (c) (B) \\
Tailing dump (TD) & 4,33 (a) (A) & $3,82(\mathrm{a})(\mathrm{A})$ & 4,31 (a) (A) & 4,20 (a) (A) \\
TD + 25\% sludge & 6,55 (b) (A) & 8,54 (c) (B) & 9,36 (c) (C) & 11,81 (c) (D) \\
TD + 50\% sludge & 6,98 (b) (A) & 8,59 (c) (B) & 11,45 (c) (C) & 23,49 (d) (D) \\
\hline
\end{tabular}

Keterangan: angka-angka yang diikuti oleh huruf kecil yang sama dalam kolom yang sama dan angka-angka yang diikuti oleh huruf besar yang sama dalam baris yang sama menunjukkan tidak berbeda nyata menurut uji DMRT pada selang kepercayaan $95 \%$

Tabel 5. Pengaruh Sludge terhadap Kandungan K pada Tailing (ppm)

\begin{tabular}{ccccc}
\hline \multirow{2}{*}{ Perlakuan } & \multicolumn{4}{c}{ Waktu (Hari ke-) } \\
\cline { 2 - 5 } & 0 & 5 & 10 & 15 \\
\hline Tailing pond (TP) & 0,050 (a) & 0,044 (a) & 0,045 (a) & 0,054 (a) \\
TP + 25\% sludge & 0,042 (a) & 0,046 (a) & 0,044 (a) & 0,045 (a) \\
TP + 50\% sludge & $0,042(\mathrm{a})$ & 0,042 (a) & 0,046 (a) & 0,043 (a) \\
Tailing dump (TD) & 0,047 (a) & 0,043 (a) & 0,048 (a) & 0,044 (a) \\
TD + 25\% sludge & 0,044 (a) & 0,046 (a) & 0,043 (a) & 0,037 (a) \\
TD + 50\% sludge & $0,040(\mathrm{a})$ & 0,043 (a) & 0,044 (a) & 0,046 (a) \\
\hline
\end{tabular}

Tabel 6. Pengaruh Sludge terhadap Nilai pH pada Tailing

\begin{tabular}{ccccc}
\hline \multirow{2}{*}{ Perlakuan } & \multicolumn{4}{c}{ Waktu (Hari ke-) } \\
\cline { 2 - 5 } & 0 & 5 & 10 & 15 \\
\hline Tailing pond (TP) & 7,23 & 7,27 & 7,33 & 7,43 \\
TP + 25\% sludge & 4,13 & 6,23 & 6,70 & 7,13 \\
TP + 50\% sludge & 4,33 & 6,77 & 7,07 & 7,17 \\
Tailing dump (TD) & 7,47 & 7,47 & 7,43 & 7,50 \\
TD + 25\% sludge & 4,23 & 6,63 & 6,97 & 7,13 \\
TD + 50\% sludge & 4,23 & 6,97 & 7,17 & 7,30 \\
\hline
\end{tabular}

Setelah dilakukan penambahan sludge semua perlakuan menunjukkan terjadi sedikit penurunan pH menjadi mendekati netral. Hal ini terjadi karena adanya reaksi buffering (penyanggaan) akibat penambahan sludge (Stevenson, 1994). Sludge menurut hasil penelitian Widyati (2006) merupakan bahan organik, dengan kandungan C organik rata-rata lebih dari $11 \%$. Menurut Bohn, dkk., (1985) bahan organik bersifat amfotir, yaitu pada saat $\mathrm{pH}$ lingkungan tinggi akan menurunkan $\mathrm{pH}$ tetapi pada saat $\mathrm{pH}$ rendah akan meningkatkan $\mathrm{pH}$ menuju ke arah netral. Kapasitas tukar kation (KTK) merupakan salah satu sifat kimia yang penting bagi tanah. Hal ini karena KTK menggambarkan jumlah muatan negatif yang tersedia untuk menangkap kation. KTK merupakan kemampuan tanah untuk mengikat unsur hara yang terdapat dalam larutan tanah (nutrient holding capacity) sehingga akan sangat menentukan ketersediaan unsur hara (Havlin, dkk., 1999). Tabel 7 menunjukkan bahwa penambahan sludge dapat meningkatkan 
KTK secara signifikan. Hal ini karena sludge merupakan bahan organik yang berasal dari limbah pemrosesan kayu menjadi kertas sehingga dapat meningkatkan KTK. Menurut Stevenson (1994) bahwa bahan organik merupakan sumber muatan (kation) yang akan meningkatkan KTK.

C. Pengaruh Sludge terhadap Ketersediaan Sulfur dan Logam-logam Berat pada Tailing

Hasil karakterisasi awal menunjukkan bahwa antara tailing pond dan tailing dump tidak menunjukkan perbedaan yang nyata, maka pada penelitian penurunan konsentrasi sulfur dan logam berat ini dipilih tailing dump yang merupakan tailing yang siap dibuang.

Gambar 1 menunjukkan bahwa penambahan sludge dapat menurunkan konsentrasi $\mathrm{S}$ dalam tailing. Hal ini diduga akibat aktivitas bakteri pereduksi sulfat (Gambar 2) yang ditemukan mengkoloni sludge industri kertas. Bakteri pereduksi sulfat (BPS) menggunakan bahan organik dalam sludge sebagai sumber karbon dan ion sulfat sebagai sumber energi (akseptor elektron). Reaksi reduksi sulfat oleh BPS menghasilkan $\mathrm{H}_{2} \mathrm{~S}$ yang akan dengan segera bereaksi dengan logam-logam membentuk senyawa logam sulfida yang sukar larut (insolubel metal-sulphides). Dengan demikian adanya BPS selalin dapat menurunkan ketersediaan $\mathrm{S}$ juga akan menurunkan ketersediaan logam-logam dalam tailing.

Tabel 8 menunjukkan bahwa penambahan sludge dapat menurunkan ketersediaan logamlogam. Menurunnya konsentrasi logam akibat penambahan sludge tersebut terjadi melalui proses pembentukan kompleks atau kelasi oleh bahan organik. Pembentukan kompleks adalah reaksi antara suatu ion logam dengan ligan melalui pembagian pasangan elektron (Tan, 1993). Ion logam merupakan pasangan penerima elektron sedangkan ligan merupakan donor elektron. Hasil penelitian ini sejalan dengan Stevenson (1994) bahwa pembentukan kompleks yang stabil antara logam dengan bahan organik dapat menurunkan toksisitas logam-logam berat misalnya $\mathrm{Cd}$ dan $\mathrm{Pb}$. Pembentukan kompleks organik-logam sangat umum terjadi di alam antara unsur logam transisi ( $\mathrm{Al}, \mathrm{Fe}, \mathrm{Mn}, \mathrm{Zn}$ dan $\mathrm{Cu}$ ). Reaksi dengan logam transisi ini sering terjadi secara khusus

Tabel 7. Pengaruh Perlakuan terhadap KTK Tailing 15 Hari setelah Inkubasi

\begin{tabular}{ccc}
\hline \multirow{2}{*}{ Perlakuan } & \multicolumn{3}{c}{ Waktu (Hari ke-) } \\
\cline { 2 - 4 } & Hari ke-0 & Hari ke-15 \\
\hline Tailing pond (TP) & $5,41 \quad$ (a) & 6,67 (a) \\
TP + 25\% sludge & 6,73 (a) & 9,55 (b) \\
TP + 50\% sludge & 8,42 (b) & 10,49 (b) \\
Tailing dump (TD) & 5,60 (a) & 6,29 (a) \\
TD + 25\% sludge & 7,73 (a) & 11,17 (b) \\
TD + 50\% sludge & 13,55 (b) & 14,24 (b) \\
\hline
\end{tabular}

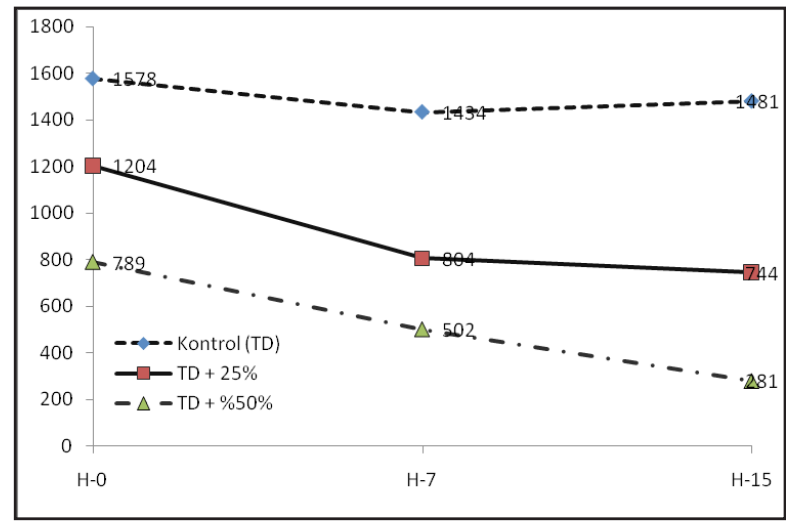

Gambar 1. Pengaruh Aplikasi Sludge terhadap Ketersediaan Sulfur (ppm) pada Hari ke-0, 7 dan 15 Hari setelah Inkubasi 
Tabel 8. Pengaruh Penambahan Sludge terhadap Konsentrasi Logam-logam (ppm) pada Tailing Dump

\begin{tabular}{|c|c|c|c|c|c|c|c|c|c|c|c|c|c|c|c|}
\hline \multirow{3}{*}{ Perlakuan } & \multicolumn{15}{|c|}{ Konsentrasi Mineral Hari ke - } \\
\hline & \multicolumn{3}{|c|}{$\mathrm{Fe}$} & \multicolumn{3}{|c|}{$\mathrm{Cu}$} & \multicolumn{3}{|c|}{$\mathrm{Pb}$} & \multicolumn{3}{|c|}{$\mathrm{Cd}$} & \multicolumn{3}{|c|}{$\mathrm{CN}$} \\
\hline & 0 & 7 & 15 & 0 & 7 & 15 & 0 & 7 & 15 & 0 & 7 & 15 & 0 & 7 & 15 \\
\hline Kontrol & 23863 & 21681 & 22444 & 120 & 123 & 121 & 147 & 161 & 145 & 13.8 & 13.6 & 13.8 & 0.76 & 0.55 & 0.64 \\
\hline $25 \%$ sludge & 21643 & 20886 & 18741 & 101 & 97 & 84 & 147 & 144 & 133 & 6.3 & 6.0 & 1.8 & 0.18 & 0.21 & $<.001$ \\
\hline $50 \%$ sludge & 21341 & 17557 & 8656 & 114 & 86 & 32 & 133 & 132 & 69 & 6.0 & 5.2 & 1.4 & 0.26 & 0.08 & $<0.001$ \\
\hline
\end{tabular}

Tabel 9. Hasil Penghitungan Efisiensi Peningkatan Unsur Hara Makro dan KTK ( dalam \%)

\begin{tabular}{lcccc}
\hline \multicolumn{1}{c}{ Perlakuan } & $\mathrm{N}$ & $\mathrm{P}$ & $\mathrm{K}$ & $\mathrm{KTK}$ \\
\hline TP & 0 & 0 & 0 & 12,3 \\
TP + 25\% sludge & 1086 & 181,2 & -21 & 99,5 \\
TP $+50 \%$ sludge & 3243 & 442,5 & -3 & 154,3 \\
TD & 0 & 3,89 & 8 & 23,3 \\
TD + 25\% sludge & 1029 & 100,2 & -10 & 76,5 \\
TD $+50 \%$ sludge & 2414 & 150,8 & -6 & 93,9 \\
\hline
\end{tabular}

yaitu logam-logam tersebut diserap oleh gugus organik. Sebagian besar kompleks organometal adalah insoluble sehingga dapat mencegah akumulasi logam dalam air tanah (Tan, 1993).

Turunnya konsentrasi logam dalam tailing akibat penambahan sludge juga dapat terjadi karena logam-logam tersebut berikatan dengan sulfida yang dihasilkan akibat tereduksinya sulfat baik secara kimia maupun akibat aktivitas bakteri pereduksi sulfat (Gambar 2). Menurut Hards dan Higgins (2004) bahwa terbentuknya sulfida akibat reaksi reduksi sulfat oleh bakteri akan berikatan dengan logam-logam dan membentuk sulfida logam yang imobil. Akibat presipitasi logamlogam ini maka kelarutan logam menjadi sangat rendah sehingga tidak meracuni lingkungan.

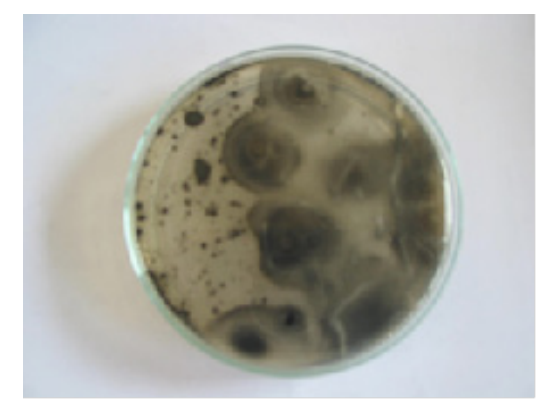

Gambar 2. Isolat Bakteri Pereduksi Sulfat (BPS) yang Ditemukan Mengkoloni Sludge

\section{Efisiensi Ameliorasi}

Efisiensi dihitung berdasarkan kondisi awal (H0) kontrol dengan kondisi akhir (H15) perlakuan dalam satuan persen (\%). Tabel 9 menunjukkan bahwa sludge efektif meningkatkan ketersediaan $\mathrm{N}$ baik pada tailing dump maupun tailing pond baik pada dosis aplikasi $25 \%$ maupun $50 \%$ setelah diinkubasi selama 15 hari. Seperti telah disebutkan di atas, bahwa efektivitas peningkatan ini diduga akibat pengaruh mikroba yang mengkoloni sludge. Pada ketersediaan $\mathrm{P}$, sludge dapat meningkatkan ketersediaan unsur tersebut minimal dua kali lipat (100\%) pada dosis aplikasi 25\% pada hari ke-15 setelah inkubasi pada tailing dump. Sedangkan pada tailing pond bahan ini pada dosis $50 \%$ dalam waktu inkubasi yang sama dapat meningkatkan ketersediaan P lebih dari lima kali lipat (>400\%) (Tabel 9).

Hasil penghitungan efisiensi penurunan konsentrasi logam-logam pada tailing dump menunjukkan bahwa dosis aplikasi yang paling efisien adalah 50\% (Tabel 10). Pada dosis tersebut setelah 15 hari inkubasi mampu menurunkan ketersediaan S 82\%, Fe 63\%, Cd tersisa $10 \%$ bahkan $\mathrm{CN}$ hampir semuanya dapat diendapkan (tersisa 0,2\%) (Tabel 10). 
Tabel 10. Hasil Penghitungan Efisiensi Penurunan Beberapa Mineral dan Logam (dalam \%)

\begin{tabular}{lcccccc}
\hline \multicolumn{1}{c}{ Perlakuan } & $\mathrm{S}$ & $\mathrm{Fe}$ & $\mathrm{Cu}$ & $\mathrm{Cd}$ & $\mathrm{Pb}$ & $\mathrm{CN}$ \\
\hline $\mathrm{TD}$ & 6,1 & 5,9 & 0,0 & 0,0 & 1,3 & $-16,4$ \\
$\mathrm{TD}+25 \%$ sludge & 52,9 & 21,5 & 30,0 & 87,0 & 9,5 & 99,8 \\
$\mathrm{TD}+50 \%$ sludge & 82,2 & 63,7 & 73,3 & 90,0 & 53,6 & 99,8 \\
\hline
\end{tabular}

\section{KESIMPULAN}

Sludge industri pulp dan kertas efektif untuk memperbaiki sifat-sifat kimia tailing bekas tambang emas. Aplikasi sludge pada dosis 50\% $(1: 1 \mathrm{v} / \mathrm{v})$ dapat meningkatkan ketersediaan ketersediaan $\mathrm{N}$ sebesar $2414 \%$ pada tailing dump dan sebesar $3243 \%$ pada tailing pond; meningkatkan ketersediaan P lebih dari $440 \%$ serta meningkatkan KTK lebih dari $150 \%$, serta menurunkan ketersediaan S (82\%), $\mathrm{Fe}(63 \%), \mathrm{Cu}$ (73\%), Cd (90\%), Pb (53\%) serta sianida (CN) sebesar 99\% pada tailing dump dalam waktu 15 hari setelah inkubasi.

\section{SARAN}

Penelitian ini masih memiliki banyak kelemahan. Oleh karena itu perlu dilakukan penelitian untuk mengetahui mengapa terjadi dinamika peningkatan ketersediaan $\mathrm{N}$ dan $\mathrm{P}$, mengapa ketersediaan $\mathrm{K}$ semakin menurun dengan penambahan sludge serta perlu penelitian untuk mengetahui pengaruh ameliorasi terhadap pertumbuhan tanaman.

\section{DAFTAR PUSTAKA}

Alloway, B.J., 1995, Heavy Metals in Soils, $2^{\text {nd }}$ ed. Blackie Academic \& Professional, London, pp: 122, 179, 206.

Andri, M. 2006, Pemanfaatan Sludge Industri Kertas untuk Memperbaiki Kesuburan Tanah Bekas Tambang Batubara, Skripsi, Departemen Ilmu Tanah dan Sumber Daya Lahan. Fakultas Pertanian IPB, Bogor

Anonim, 2012, Bahan Kuliah Dampak Pertambangan Terhadap Sifat Fisik dan Kimia Tanah. Dapat diakses di: https:// ismedinonu. ubb.ac.id/wp-content/uploads/2012/04/ KULIAH-3.-DAMPAK-THP-SIFAT-FISIKDAN-KIMIA-TANAH.pptx

Bohn, H.L., B.L.McNeal dan G.A.O'Connor, 1985, Soil Chemistry. $2^{\text {nd }}$ ed. John Willey\&son. New York (pp: 135 - 152)
Ditjen Pertambangan Mineral dan Batubara, 2007, Penyebaran Cadangan Bahan Galian Indonesia. www.dpmb.esdm.go.id

Fauziah A. B., 2009, Pengaruh Asam Humat dan Kompos Aktif untuk Memperbaiki Sifat Tailing dengan Indikator Pertumbuhan Tinggi Semai Enterolobium cyclocarpum Griseb dan Altingia excelsa Noronhae .Skripsi, Departemen Silvikultur Fakultas Kehutanan, Institut Pertanian Bogor.

Gautama, R.S., 2007, Pidato Guru Besar ITB: Pengelolaan air asam tambang: aspek penting menuju pertambangan berwawasan lingkungan, www.itb.ac.id/favicon.ico [20 Mei 2007]

Hards, B.C., dan J.P. Higgins., 2004, Bioremediation of Acid Rock Drainage Using Sulphate Reducing Bacteria, Jacques Whit Environment Limited. Ontario (pp: 67 - 86)

Harian BERITA SORE Makassar, edisi 11 Februari 2009, Siaran pers Menko Ekonomi: Indonesia Potensi Tambang Nomor Enam Terkaya, Tersedia di: http://beritasore.com/news/wpcontent/themes/flashnews/images/favicon.ico

Havlin, J.L., J.D. Beaton, S.L. Tisdale and W.L. Nelson., 1999, Soil Fertility and Fertilizer: An Introduction to Nutrient Management. Prentice Hall, New Jersey (pp: 144 - 161)

Hidayat, Y., Christiantoko dan E. Suprapto. 2007, Masih Banyak Emas Selain Busang: Potret tambang emas Batuhijau di Sumbawa. http://www.hamline.edu/apakabar/ basisdata/1997/02/07/0013.html

Kshirsagar, S dan N.C. Aery., 2007, Phytostabilization of mine waste : Growth and physiological responsesof Vigna unguiculata (L.) Walp. Journal of Environmental Biology: 28(3) 651-654

Maemunah, S., 2007, Emas, Lembata dan Merukh. Dimuat di Harian Flores Pos, 30 Juli 2007, dapat diakses di:www.jatam.org.

N'Dayegamiye, A., 2009, Mixed Paper Mill Sludge Effects on Corn Yield, Nitrogen Efficiency, and Soil Properties. Agronomy Journal (98):1471-1478 
Pusat Penelitian Tanah, 1993, Interpretasi Data Kesuburan dan Penyusunan Rekomendasi, Pusat Penelitian Tanah Departemen Pertanian (Tidak diterbitkan).

Rosenburg, L.V., M.S. Maboeta and M.L Mogenthal., 2004, Rehabilitation of Codisposed Diamond Tailing: Growth medium rectification procedures and indigenous grass establishment. Water, Air and Soil Pollution Journal, Vol 154. no. 1-4 (101-113).

Setyawan, D.R., 2004, Sistem Pembuangan Tailing ke Laut PT NMR, Dapat diakses di: http://www.walhi.or.id/ kampanye/tambang/ buanglimbah/tam_tailing_std_nmr/

Siregar, C.A., 2005, Pemanfaatan Cendawan Mikoriza dan Pupuk Organik untuk Memperbaiki Pertumbuhan Gmelina arborea Pada Tanah Tailing Terkontaminasi $\mathrm{Pb}$ dan $\mathrm{Fe}$ di Area Penambangan Emas, Pongkor. Jurnal Penelitian Kehutanan, Vol 3 (4): 56-64.

Sitorus, S.R.P., E. Kusumastuti, dan L. N. Badri. 2008, Karakteristik dan Teknik Rehabilitasi Lahan Pasca Penambangan Timahdi Pulau Bangka dan Singkep. Abstrak. Jurnal Tanah dan Iklim. No. 27 (2008).
Stevenson, F.J., 1994, Humus Chemistry: Genesis, Composition, Reaction, John Willey\&son, New York (pp: 66 - 74)

Tan, K.H., 1993, Principles of Soil Chemistry $\left(2^{\text {nd }} E d\right)$, Marcel Dekker Inc, New York, (pp: $205-237)$

Wasis, B. dan A. Sandrasari. 2011, Pengaruh Pemberian Pupuk Kompos terhadap Pertumbuhan Semai Mahoni (Swietenia macrophylla King.) pada Media Tanah Bekas Tambang Emas (Tailing), Jurnal Silvikultur Tropika Vol. 03 No. 01 Agustus 2011, Hal. $109-112$

Widyati, E., 2006, Bioremediasi Tanah Bekas Tambang Batubara dengan Sludge Industri Kertas untuk Memacu Revegetasi Lahan. Disertasi. Program Pendidikan Doktor, IPB. Bogor.

Witoko, D., 2011, Perbaikan Ketersediaan Unsur Hara Makro Tailing Tambang Emas dengan Sludge Industri Kertas untuk Media Tanam, Skripsi, Departemen Ilmu Tanah dan Sumberdaya Lahan. IPB. Bogor. 